\title{
HEART RATE AND TIME-MOTION ANALYSES IN TOP JUNIOR PLAYERS DURING BASKETBALL MATCHES
}

\author{
Karel Hůlka, Roman Cuberek, Jan Bělka
}

Faculty of Physical Culture, Palacký University, Olomouc, Czech Republic

Submitted in December, 2012

BACKGROUND: Basketball performance can be classified as an intermittent physical activity due to the changing situational game conditions and the number of intervening variables. It is necessary to have detailed knowledge about the performance of basketball players during a match as a background for more specific planning of the training process.

OBJECTIVE: The aim of this study was to analyse the indicators of internal and external load of basketball player's performance during a match of U18 top men basketball players as a background for the planning of specific training processes.

METHODS: Thirty-two Czech top junior basketball players (male, aged $16.88 \pm 0.72$ years) participated in this research. The heart rate was recorded and time-motion analysis was conducted during six warm-up matches.

RESULTS: The average heart rate was measured to be $167.47 \pm 13.01$ beats $\cdot$ min. $^{-1}$, which corresponded to $85.06 \pm 6.40 \%$ of peak heart rate. The percentages of the total time spent over and under $85 \%$ were $63.12 \%$ and $36.88 \%$, respectively. Average distance covered was measured to be 5,880.91 \pm 831.01 meters. The average work : rest ratio was $1: 7.95 \pm 1.83$, ranging from $1: 4.80$ to $1: 10.92$.

CONCLUSIONS: The results from these matches suggest that the exercise intensity and sprint activity observed during junior basketball are dependent on the player's position and partly on the level of the performance. The heart rate during a match was not dependent on the positions, however, time-motion analysis revealed significant differences between three basketball positions during a match. The combination of heart rate and time-motion analysis is recommended.

Keywords: Exercise intensity, conditioning, metabolic demands, $H R$

\section{INTRODUCTION}

The increase in a player's performance depends upon the quality of their training. As in most sports, the quality of basketball training is related to match performance simulation (Taylor, 2003). Therefore, the basketball training process should include demands similar to match play (Hůlka \& Stejskal, 2005). Basketball performance can be classified as an intermittent physical activity (Ben Abdelkrim, El Fazaa, \& El Ati, 2007) due to the changing situational game conditions and the number of intervening variables. These variables are characterised by irregular changes, occurring in very short time periods (up to $10 \mathrm{~s}$ ), between a high intensity and a low intensity activities that are connected with recovery (passive or active) processes (Christ-

\footnotetext{
* Address for correspondence: Karel Hůlka, Department of Sport, Faculty of Physical Culture, Palacký University, tř. Míru 115, 77111 Olomouc, Czech Republic. E-mail: karel.hulka@upol.cz
}

mass, Dawson, \& Arthur, 1999; Krustrup et al., 2006; Narazaki, Berg, Stergiou, \& Chen, 2009). Intermittent performance depends on a combination of aerobic and anaerobic capacity (Green et al., 1976; Sallet, Perrier, Ferret, Vitelli, \& Baverel, 2005), making performance analysis substantially more complicated. The complexity of performance analysis is the primary reason why the association between the capacities and limitations of basketball has not been sufficiently described yet (Girard, Mendez-Villanueva, \& Bishop, 2011). The physiological demands of basketball performance during a match, represented by indicators of internal load (heart rate every $5 \mathrm{~s}$, peak heart rate zones) and external load (distance covered, speed, work : rest ratio, types of locomotion), should be considered as a background for the planning of specific basketball training processes in order achieve the required adaptations of aerobic and anaerobic metabolism. According to Ziv and Lidor (2009), only a few studies have been performed to observe the basketball performance of players. In addition, not all studies make use of sophisti- 
cated, standardised methods of time-motion analysis. Further research into basketball performance should be conducted for these reasons.

Some researchers have studied basketball match performance. Ben Abdelkrim et al. (2007) examined internal load, expressed by average heart rate, and found that $91 \pm 2 \%$ of peak heart rate $\left(\mathrm{HR}_{\text {peak }}\right)$ of players (national Tunisian U19 team) was achieved during a warm up match. Ziv and Lidor (2009) stated that $86.20 \pm 5.30 \%$ of $\mathrm{HR}_{\text {peak }}$ was achieved during the first half and that $86.70 \pm 4.30 \%$ of $\mathrm{HR}_{\text {peak }}$ was achieved during the second half of the warm up match (U18 category). Average heart rate, measuring from 87 to $91 \%$ of $\mathrm{HR}_{\text {peak, }}$ was examined in studies that focused on a cohort of top senior basketball players (Matkovič R. B., Matkovič B., \& Knajz, 2005; McInnes, Carlson, Jones, \& McKenna, 1995; Montgomery, Pyne, \& Minanhan, 2010). Narazaki, Berg, Stergiou, and Chen (2009) measured the heart rate of six National Collegiate Athletic Association second league players (aged 20.8 years) and observed an average heart rate of $169.30 \pm 4.50$ beats $\cdot \min .^{-1}$. Erčulj et al. (2008) studied three playoff matches from the Slovenian basketball league to observe distances covered as a marker of external loading. In total, the players covered 6,235 meters. Narazaki et al. (2009) measured distances of 4,500 to 6,000 meters covered during a match. It is believed that it is necessary to obtain more detailed information about basketball performance during a match (Borin, Goncalves, Padovani, \& Aragon, 2005). In contrast with studies of other sports, few studies of basketball have conducted time-motion analysis using sophisticated methods (Ziv \& Lidor, 2009).

The aim of this study was to analyse the indicators of the internal (mean heart rate, $\mathrm{HR}_{\text {peak }}$ zones) and external (distance covered, work: rest ratio) loads of basketball player's performance during a match between U18 top men basketball players as a background for the planning of specific training processes.

\section{METHODS}

\section{Participants}

Thirty-two players from the elite Czech national basketball league, in the U18 category, were observed (male, aged 16.88 \pm 0.72 year; height $192.10 \pm 6.49 \mathrm{~cm}$; weight $83.74 \pm 13.60 \mathrm{~kg}$; HR $197.28 \pm 5.48$ beats $\cdot$ min $\left.^{-1}\right)$. They trained five times per week (four technical-tactical practices and one conditioning practice). All procedures were conducted during the pre-competitive part of season (August and September). All of the participants were informed about the goal of the recording their match and the subsequent findings. Participation in this study was voluntary, and the video recording was used only for the purposes of the study. Upon consenting to the recording of their games, through written informed consent, the aims and objectives of the study were clarified to all basketball players invited to participate in the research.

\section{Procedures}

The indicators of external (distance covered, speed, work : rest ratio) and internal (heart rate every $5 \mathrm{~s}$, $\mathrm{HR}_{\text {peak }}$ zones) loads were observed during basketball warm up matches.

The peak heart rate for each player was determined by completion of the Léger beep test (Léger $\&$ Lambert, 1982). The measurement was made during practices, after one day off (Tuesday), one week before the first measured match. Heart rate measures were performed using the TEAM Polar ${ }^{2}$ Pro system (Polar Electro, Kempele, Finland) and results were expressed as a percentage of $\mathrm{HR}_{\text {peak }}$.

Six warm up matches, between teams from the elite Czech national basketball league in the U18 category, were recorded. Each match consisted of four $10 \mathrm{~min}$. quarters, with $2 \mathrm{~min}$. breaks after the first and third quarters and a $15 \mathrm{~min}$. half time. All matches followed official basketball rules and were officiated by two referees. The observed participants used blue T-shirts with large orange numbers (corresponding with official basketball rules) to permit clear identification. The basketball court was of standard size $(28 \times 15 \mathrm{~m})$ and differed in colour from the T-shirts of the participants. The footage was recorded with two Canon HF10 video cameras (each with a resolution of $1280 \times 720$ pixels). Each camera was used to record a separate half of the court. One video camera was placed perpendicular to the side line $(620 \mathrm{~cm}$ above the surface, $840 \mathrm{~cm}$ from the side line) in the middle of the first recorded half of the basketball court. The second camera was placed in an analogous manner to record the second half of the court. The video recording was then exported to the VMMT 1.0 software and subsequently calibrated by use of the lines marking the court, the real positions of the court lines are known.

Video records were analysed by a standardised procedure using a software package (Video Manual Motion Tracker 1.0, Faculty of Physical Culture, Palacký University Olomouc, Czech Republic). This method enables the recording of the total distance covered during a match. Additionally, this method allows for measurement of the immediate and average velocity of the players during a match or a training. Next, the intensity profile of player's performance was grouped, according to Barbero-Alvarez J., Soto, 
Barbero-Alvarez V., and Granda-Vera (2008) and Bishop and Wright (2006), as follows:

- low intensity activity ( 0 to $\left.3.00 \mathrm{~m} \cdot \mathrm{s}^{-1}\right)$, included inactivity (to $\left.0.10 \mathrm{~m} \cdot \mathrm{s}^{-1}\right)$, walking $(0.10$ to $\left.1.00 \mathrm{~m} \cdot \mathrm{s}^{-1}\right)$, jogging $\left(1.10\right.$ to $\left.3.00 \mathrm{~m} \cdot \mathrm{s}^{-1}\right)$,

- medium intensity activity $\left(3.10\right.$ to $\left.5.00 \mathrm{~m} \cdot \mathrm{s}^{-1}\right)$,

- high and maximal intensity activity (over $\left.5.10 \mathrm{~m} \cdot \mathrm{s}^{-1}\right)$.

Each player was fitted with TEAM Polar ${ }^{2}$ Pro sport testers (Polar Electro, Kempele, Finland) which were set to monitor the heart rate of players during a match as an internal load indicator. We expressed the measured data as a percentage of $\mathrm{HR}_{\text {peak }}$ (Ben Abdelkrim et al., 2007; Capranica, Tessitore, \& Guidetti, 2001; Hoffman, 2002; McInnes, Carlson, Jones, \& McKenna, 1995; Rodriguez-Alonzo, Fernandez-Garcia, PerezLandaluce, \& Terrados, 2003; Tessitore, Tiberi, Cortis, Rapisarda, \& Meeuesen, 2006).

To allow comparison of our data with those of other studies, we utilised six $\mathrm{HR}_{\text {peak }}$ zones, as described by McInnes et al. (1995), Ben Abdelkrim et al. (2007), and Bishop \& Wright (2006). The $\mathrm{HR}_{\text {peak }}$ zones were defined as follows $<75 \% \mathrm{HR}_{\text {peak }}, 75 \% \leq \mathrm{HR} \leq 80 \% \mathrm{HR}_{\text {peak }}$, $80 \% \leq \mathrm{HR} \leq 85 \% \mathrm{HR}_{\text {peak }}, 85 \% \leq \mathrm{HR} \leq 90 \% \mathrm{HR}_{\text {peak }}, 90 \%$ $\leq \mathrm{HR} \leq 95 \% \mathrm{HR}_{\text {peak }}$, and $\geq 95 \% \mathrm{HR}_{\text {peak }}$.

\section{STATISTICAL ANALYSES}

A statistical software package, Statistica 8 (StatSoft Inc., Tulsa, OK, USA), was used to compute all statistical characteristics (mean, standard deviation of measured variables, heart rate zones of $\mathrm{HR}_{\text {peak }}$ ). Descriptive statistics were used.

To detect systematic bias, repeated-measures analysis of variance was applied. The statistical significance of all parts of the analysis was determined at an alpha level of $p<.05$. The standard error of measurement (SEM) and Bland and Altman's 95\% limits of agreement for repeated measurements were used to express and assess the intra-individual test retest reliability (Atkinson \& Nevill, 1998). To calculate the SEM, the following formula was used (Thomas, Nelson, \& Silverman, 2005) $-S E M=s \cdot \sqrt{(1-I C C)}$ where $s$ is the standard deviation of the sample and ICC is the calculated intraclass correlation coefficient. A normality test was used to ascertain the normal distribution of variables. The analysis of variance was used to compare three basketball positions (guards, wings, and centres). The $\omega^{2}$ effect size coefficient was calculated as a $\omega^{2}=[F \cdot(k-1)]-k+1 /[F \cdot(k-1)]+n-k+1$, where $F$ is value of the analysis of variance, $k$ is number of groups, and $n$ is number of participants.

\section{RESULTS}

\section{The intra-individual reliability}

Table 1 presents the results of the reliability analysis. According to repeated-measures ANOVA findings, at a five-percent significance level, there are no statistically significant differences between the results of the six matches. Thus, there was no detection of systematic bias for all measured variables. Similarly, the high value of the ICC of distance covered and average $\% \mathrm{HR}_{\text {peak }}$ during a match implies a very high level of intra-individual consistency, however, this trend does not apply to average speed and measurement of intensity variables. SEM and Bland and Altman's 95\% limits of agreement for repeated measurements interpret the absolute values of reliability.

\section{Heart rate}

By monitoring heart rate during the match, the average heart rate was observed to be $167.47 \pm 13.01$ beats $\cdot \min .^{-1}$, which corresponded to $85.06 \pm 6.40 \%$ of $\mathrm{HR}_{\text {peak }}$. The values ranged from $71.65 \%$ to $97.07 \%$ of $\mathrm{HR}_{\text {peak }}^{\text {peak }}$.

Figure 1 represents the percentage of time spent in each zone composed of the $\mathrm{HR}_{\text {peak }}$ percentages of the monitored players during the basketball match. It was apparent that a player spent most of the time in the zone of maximal load intensity ( $\left.90-95 \% \mathrm{HR}_{\text {peak }}\right)$, corresponding to $28.08 \pm 10.96 \%$ of the duration of the game. In contrast, the least amount of time was spent in the zone of $75-80 \%$ of $\mathrm{HR}_{\text {peak }}$, which corresponds to $9.15 \pm 5.98 \%$ of the game.

The players spent $63.11 \pm 16.39 \%$ of the time at over $85 \%$ of $\mathrm{HR}_{\text {peak }}$ and only $36.88 \pm 16.39 \%$ of the time under $85 \%$ of $\mathrm{HR}_{\text {peak }}$. The ratio of time spent over and under $85 \%$ of $\mathrm{HR}_{\text {peak }}^{\text {peak }}$ was $63.11: 36.88$, which corresponds to the ratio $1.71: 1$.

In regards to the player position (guard, wings, centre), guards displayed the highest average percentage of $\mathrm{HR}_{\text {peak }}$ while the lowest average percentages of $\mathrm{HR}_{\text {peak }}$ were associated with the wing position. There were no statistically significant differences between the player positions. All values are displayed in Table 2.

\section{Time-motion analysis}

Average distance covered was measured to be $5,880.91 \pm 831.01 \mathrm{~m}$. The shortest distance covered was $4,122.46$ meters and the longest $6,919.75$ meters. These values were achieved with an average speed of $2.40 \pm 0.20 \mathrm{~m} \cdot \mathrm{s}^{-1}$ or $8.64 \pm 0.81 \mathrm{~km} \cdot \mathrm{h}^{-1}$. This speed is computed from the total time spent on the court with dead ball time included. The highest average speed was $2.79 \mathrm{~m} \cdot \mathrm{s}^{-1}\left(10.05 \mathrm{~km} \cdot \mathrm{h}^{-1}\right)$ and the lowest was $2.01 \mathrm{~m} \cdot \mathrm{s}^{-1}\left(7.18 \mathrm{~km} \cdot \mathrm{h}^{-1}\right)$.

The highest percentage of time was spent in low intensity zone $(68.77 \pm 4.19 \%)$ and the lowest per- 
Table 1

Reliability of time-motion heart rate measurement

\begin{tabular}{|c|c|c|c|c|}
\hline & ANOVA & ICC & SEM & $95 \%$ LoA \\
\hline HR & $\begin{array}{l}F=0.26 \\
p=.77\end{array}$ & .96 & $1.05 \mathrm{~b} \cdot \mathrm{min}^{-1}$ & $\pm 2.96 \mathrm{~b} \cdot \mathrm{min}^{-1}$ \\
\hline Dist. & $\begin{array}{l}F=0.53 \\
p=.59\end{array}$ & .90 & $111.07 \mathrm{~m}$ & $\pm 217.70 \mathrm{~m}$ \\
\hline Speed & $\begin{array}{l}F=0.42 \\
p=.66\end{array}$ & .54 & $0.12 \mathrm{~m} \cdot \mathrm{s}^{-1}$ & $\pm 0.23 \mathrm{~m} \cdot \mathrm{s}^{-1}$ \\
\hline Jumps & $\begin{array}{l}F=1.64 \\
p=.21\end{array}$ & .88 & 5.02 & \pm 9.84 \\
\hline$<2$ s sprint & $\begin{array}{l}F=1.38 \\
p=.27\end{array}$ & .99 & 1.91 & \pm 3.75 \\
\hline$<4$ s sprint & $\begin{array}{l}F=1.74 \\
p=.15\end{array}$ & .78 & 6.94 & \pm 13.60 \\
\hline$>4 \mathrm{~s}$ sprint & $\begin{array}{l}F=4.60 \\
p=.02\end{array}$ & .29 & 7.86 & \pm 15.41 \\
\hline Low intensity & $\begin{array}{l}F=1.62 \\
p=.20\end{array}$ & .63 & $1.53 \%$ & $\pm 3.01 \%$ \\
\hline Medium intensity & $\begin{array}{l}F=1.340 \\
p=.27\end{array}$ & .73 & $0.94 \%$ & $\pm 1.84 \%$ \\
\hline High intensity & $\begin{aligned} F & =0.37 \\
p & =.69\end{aligned}$ & .58 & $1.39 \%$ & $\pm 2.73 \%$ \\
\hline
\end{tabular}

Note. $\quad$ ICC $=$ intraclass coefficient of correlation, $95 \%$ LoA $=$ Bland and Altman's 95\% limits of agreement, $\mathrm{HR}=$ average $\% \mathrm{HR}_{\text {peak }}$ during a match, Dist. = distance covered, $<2 \mathrm{~s}$ sprint $=$ maximal intensity activity to $2 \mathrm{~s}$ length, $<4 \mathrm{~s}$ sprint $=$ maximal intensity activity from $2 \mathrm{~s}$ to $4 \mathrm{~s}$ length,

$>4 \mathrm{~s}$ sprint $=$ maximal intensity activity over $4 \mathrm{~s}$ length.

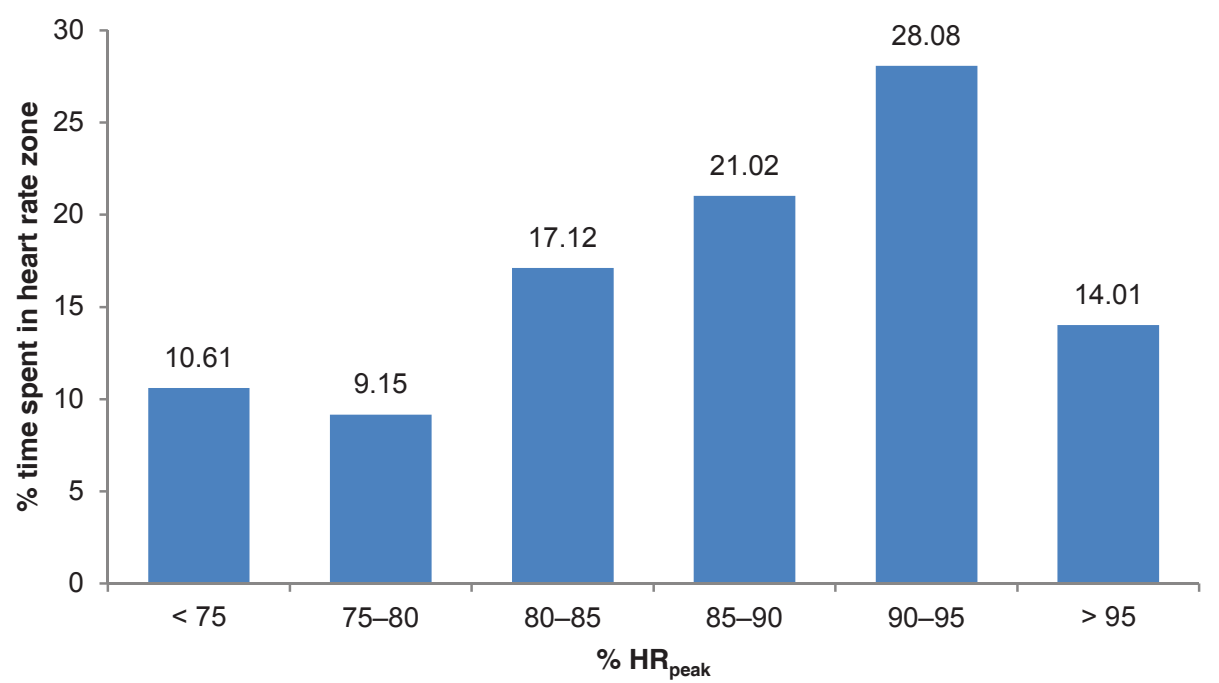

Figure 1. Percentage of time spent in heart rate zones 
centage of time was spent in the zone of high intensity $(11.79 \pm 2.75 \%)$. From the gathered percentages, we computed the interval of intermittent load to equal $1: 1.64: 5.83$. On average, this relationship determined that for every one second of high intensity load, the player spends 1.64 seconds of medium intensity and 5.83 seconds of low intensity physical activity. Through calculation of the intensity of the activities according to Taylor (2003), work:rest ratio was determined to be $1: 7.95 \pm 1.83$, from $1: 4.80$ to $1: 10.92$.

The players performed $33.31 \pm 14.92$ jumps and $210.36 \pm 31.56$ sprints during a match. When dividing sprints according to duration, it was found that $135.44 \pm 22.87$ sprints lasted $2 \mathrm{~s} \quad(64.16 \pm 6.21 \%)$, $53.69 \pm 14.67$ sprints lasted from 2 to $4 \mathrm{~s}$ $(25.77 \pm 6.14 \%)$, and $21.69 \pm 9.36$ sprints lasted over $4 \mathrm{~s}$, which represent only $9.93 \pm 3.33 \%$ of all sprints.

Table 2 shows position differences in time-motion during a basketball match. We found statistically significant differences between positions in all time-motion variables in sprints that lasted to $4 \mathrm{~s}$.

\section{DISSCUSSION}

The aim of this study was to analyse the indicators of internal (mean heart rate, $\mathrm{HR}_{\text {peak }}$ zones) and external (distance covered, work : rest ratio) load of basketball player's performance during a match of U18, top male basketball players as a background for the planning of specific training processes.

Reliability is used to describe the quality of repeated measurements. The knowledge of various sources of measurement errors may help to further the understanding of the collected data, ensure appropriate interpretation of differences and proper application to the training process.

In agreement with other research (Ben Abdelkrim et al., 2007; Erčulj et al., 2008; Matkovič et al., 2005; McInnes et al., 1995; Montgomery, Pyne, \& Minahan, 2010; Narazaki et al., 2009) on basketball players, the high intensity activities resulted in heart rates of approximately 170 beats $\cdot \min .^{-1}$. The average values in these studies were similar (from $86 \%$ to $91 \%$ ). The differences between the results are similar to the value of calculated $95 \%$ limits of agreement, and thus, these differences are considered to be negligible. According to Matthew and Delextrat (2009), Krustrup, Mohr, and Ellingsgaard (2005), and Montgomery (1988), lower values of heart rate may be partly explained by the lower playing standard in the present study or by the physical fitness levels of the players.

Very high values of the mean heart rate during a match do not correspond with the relatively low duration of high intensity activities. According to Ben Ab-

Table 2

Heart rate and time-motion characteristics in different positions

\begin{tabular}{|c|c|c|c|c|c|}
\hline & 1 & 3 & 5 & ANOVA & $\omega^{2}$ \\
\hline$\% \mathrm{HR}_{\text {peak }}$ & $88.43 \pm 8.03$ & $79.18 \pm 11.27$ & $83.42 \pm 9.19$ & $\begin{array}{l}F=0.99 \\
p=.38\end{array}$ & $<.001$ \\
\hline Dist. (m) & $6,635.13 \pm 221.10$ & $6,016.17 \pm 448.22$ & $5,225.41 \pm 659.33$ & $\begin{array}{l}F=10.73 \\
p<.001^{*}\end{array}$ & .37 \\
\hline Speed $\left(\mathrm{m} \cdot \mathrm{s}^{-1}\right)$ & $2.45 \pm 0.12$ & $2.42 \pm 0.18$ & $2.37 \pm 0.21$ & $\begin{array}{l}F=0.27 \\
p=.76\end{array}$ & .05 \\
\hline Jumps & $15.12 \pm 3.89$ & $31.18 \pm 7.27$ & $46.30 \pm 10.16$ & $\begin{array}{l}F=35.23 \\
p<.001^{*}\end{array}$ & .67 \\
\hline Low (\%) & $67.57 \pm 3.00$ & $64.97 \pm 3.17$ & $72.12 \pm 3.12$ & $\begin{array}{l}F=14.98 \\
p<.001^{*}\end{array}$ & .46 \\
\hline Medium (\%) & $21.47 \pm 2.76$ & $20.06 \pm 1.29$ & $17.64 \pm 2.16$ & $\begin{array}{l}F=9.09 \\
p<.001^{*}\end{array}$ & .33 \\
\hline High (\%) & $22.37 \pm 2.77$ & $13.56 \pm 2.44$ & $10.24 \pm 2.15$ & $\begin{array}{l}F=4.88 \\
p=.02^{*}\end{array}$ & .19 \\
\hline$<2$ s sprint & $168.37 \pm 12.15$ & $139.09 \pm 21.23$ & $112.07 \pm 21.29$ & $\begin{array}{l}F=21.00 \\
p<.001^{*}\end{array}$ & .55 \\
\hline$<4$ s sprint & $59.50 \pm 14.61$ & $58.27 \pm 14.68$ & $46.23 \pm 4.13$ & $\begin{array}{c}F=3.08 \\
p=.04 *\end{array}$ & .11 \\
\hline$>4 \mathrm{~s}$ sprint & $29.62 \pm 5.87$ & $25.55 \pm 8.59$ & $11.63 \pm 4.13$ & $\begin{array}{l}F=0.68 \\
p=.77\end{array}$ & .02 \\
\hline
\end{tabular}

Note. $\omega^{2}=$ coefficient of effect size, Dist. = distance covered, $<2 \mathrm{~s}$ sprint $=$ maximal intensity activity to $2 \mathrm{~s}$ length, $<4 \mathrm{~s}$ sprint $=$ maximal intensity activity from $2 \mathrm{~s}$ to $4 \mathrm{~s}$ length, $>4 \mathrm{~s}$ sprint $=$ maximal intensity activity over $4 \mathrm{~s}$ length . * values are significantly different on $p<.05$. 
delkrim et al. (2007) and McInnes et al. (1995), this may attributed to the specific (unorthodox) types of locomotion, including acceleration, deceleration and changes in direction. Additionally, locomotion of the players includes the involvement of the upper limbs during dribbling, shooting, and passing. Moreover, emotional stress may also increase the heart rate; however, Bangsbo, Iaia, Marcello, and Krustrup (2008) stated that this relationship is not yet entirely understood.

This study found a lower work : rest ratio than that found by Taylor (2003), where work : rest ratio was $1: 10$. This variance can be caused by different research methods. The work : rest ratio results of the present study are similar to those of Bishop et al. (2006).

When comparing the results of other cited studies to those resented here, the higher SD suggests higher variability in the data. These differences may be explained by the different levels of motivation during the game based on the varying importance of the game. Further explanation may be provided by the varying goals of national teams and players or by the quality of the opposing team and players. Lastly, differences may be due to distinctive tactical tasks and different fitness readiness of players of the monitored teams.

In the present study, the average distance covered was lower than that reported by Erčulj et al. (2008). The apparent reasons for this difference were related to the higher level of competition and higher motivation of players. The results of a study by Narazaki et al. (2009) are similar to the results presented here.

McInnes et al. (1995) stated that average sprint duration was less than $3 \mathrm{~s}$ and maximal duration of high-intensity activities were $13 \mathrm{~s}$. The results from the current study are very similar. The current study demonstrates that short high intensity activities (up to $3 \mathrm{~s}$ ) are the first key limiting factor of basketball performance. These results suggest that when planning the training process, we should concentrate on acceleration, deceleration and high intensity activities of up to $3 \mathrm{~s}$ in duration.

On average, the players performed 33.31 jumps during a match. The current number of jumps is lower than the 44 jumps reported in the study by Ben $\mathrm{Ab}$ delkrim et al. (2007), 46 in McInnes et al. (1995), and 35 in Matthew and Delextrat (2009).

During the player's performance, high intensity activities resulted in metabolic responses, such as a decrease in muscle $\mathrm{pH}$, phosphocreatine and ATP, activation of anaerobic glycolysis, and a significant involvement of aerobic metabolism (Rampinini et al., 2007; Wragg, Maxwell, \& Doust, 2000). These high intensity activities are frequently changed to low or medium intensity activities during a player's performance. The ability to repeatedly perform high intensity activi- ties may be a second key limiting factor (Spencer, Bishop, Dawson, \& Goodman, 2005). Moreover, due to the unpredictability of the game, the failure to perform the next high intensity activity may greatly affect the outcome of the match (Wadley \& Le Rossignol, 1998).

Great importance is placed on the speed and quality of the recovery processes during the periods of medium or low intensity activities (Arnett, 1996; Montgomery, 1988). The ability to quickly replenish energy stores in the working muscles during short and active rest is called repeated-sprint ability (RSA) (Girard, Mendez-Villanueva, \& Bishop, 2011).

Current results related to the players' performance during a match should be used as a basis for objective decisions in planning conditioning as a part of the prematch preparation, and, thus, indirectly affect the efficiency of the training process (Burgess, Naughton, \& Norton, 2006; Carling, Bloomfield, Nelson, \& Reilly, 2008; Dobson \& Keogh, 2007; Rudkin \& O’Donoghue, 2008; Sigmon, 2003). Taylor (2003) and Sakai, Itoh, Otaka, and Takamatsu (2006) prioritised this information before the results of any fitness measurements.

When comparing heart rate data by position, the highest $\% \mathrm{HR}_{\text {peak }}$ was attained by the guards and the lowest was attained by the wings. However, these differences not statistically significant. It could be hypothesised that basketball performance resulted in similar internal loads for all players. The results of our time-motion analysis showed differences versus those reported by Ben Abdelkrim et al. (2007). We found significantly different values in all variables except for the maximal intensity activities over $4 \mathrm{~s}$ in length.

The time-motion differences may result from the tasks connected with positions. Centres performed the most jumps because of rebounding and fewer maximal intensity activities because of their positional play around the paint. Conversely, the tasks of perimeter players (guards and wings) were connected with the perimeter movements (screening, cutting, etc.). To plan an effective training program, the program should be individualised based on player position. These timemotion differences could service as a basis for planning.

Lastly, differences between time-motion results and heart rate responses confirm the statement of Gocentas, Landõr, and Krisciunas (2011) that the monitoring of heart rate alone can be insufficient for performance analysis. Failing to use measures other than heart rate monitoring may result in fewer findings related to performance differences, thus reducing the amount of useful information for researchers and practitioners. 


\section{CONCLUSIONS}

The results from these six matches suggest that the exercise intensities and sprint activities observed during junior basketball are dependent on the player's position and partly on the level of the performance. The heart rate during a match was not dependent on the positions but the time motion analysis showed significant differences between three basketball positions during a match. Thus, a combination of heart rate and timemotion analysis is recommended.

Further research should be focused on clarifying the metabolic processes during low and moderate intensity work intervals, as this is a principal limitation of basketball performance. Furthermore, future research should examine conditioning methods and the responses to the demands of basketball performance.

\section{REFERENCES}

Arnett, M. G. (1996). Effects of specifity training on the recovery process during intermittent activity in ice hockey. Journal of Strength \& Conditioning Research, 10(2), 124-126.

Balsom, P. D. (1995). High intermittent exercise: Performance and metabolic responses with very high intensity short duration work periods. Doctoral thesis, Karolinska Institute, Stockholm.

Bangsbo, J., Iaia, F. M., Marcello, I., \& Krustrup, P. (2008). Physical and metabolic demands of training and match-play in elite football players. Journal of Sport Sciences, 24(7), 665-674.

Barbero-Alvarez, J. C., Soto, V. M., Barbero-Alvarez, V., \& Granda-Vera, J. (2008). Match analysis and heart rate of futsal players during competition. Journal of Sport Sciences, 26(1), 63-73.

Ben Abdelkrim, B. N., Chaouachi, A., Chamari, K., Chtara, M., \& Castagna, C. (2010). Positional role and competitive-level differences in elite-level men's basketball players. Journal of Strenght and Conditioning Research, 24(5), 1346-1355.

Ben Abdelkrim, N. B., El Fazaa, S., \& El Ati, J. (2007). Time-motion analysis and physiological data of elite under 19 year old basketball players during competition. British Journal of Sports Medicine, 41(2), 69-75.

Bishop, D. C., \& Wright, C. (2006). A time-motion analysis of professional basketball to determine the relationship between three activity profiles: High, medium and low intensity and the length of the time spent on court. International Journal of Performance Analysis in Sport, 6(1), 130-139.

Borin, J. P., Goncalves, A., Padovani, C. R., \& Aragon, F. F. (2005). Profile of the intensity effort of moves and timing in professional basketball games. Salusvita, 24(3), 491-498.
Burgess, D. J., Naughton, G., \& Norton, K. I. (2006). Profile of movement demands of national football players in Australia. Journal of Science and Medicine in Sport, 9(4), 334-341.

Capranica, L., Tessitore, L., \& Guidetti, L. (2001). Heart rate and match analysis in pre-pubescent soccer players. Journal of Sports Sciences, 19(6), 379-384.

Carling, Ch., Bloomfield, J., Nelson, L., \& Reilly, T. (2008). The role of motion analysis in elite soccer. Sports Medicine, 38(10), 839-862.

Christmass, M. A., Dawson, B., \& Arthur, P. G. (1999). Effect of work and recovery duration on skeletal muscle oxygenation fuel use during sustained intermittent exercise. European Journal of Applied Physiology, 80(5), 436-447.

Dobson, B. P., \& Keogh, W. L. (2007). Methodological issues for the application of time-motion analysis research. Strength and Conditioning Journal, 29(2), 48-55.

Erčulj, F., Dežman, B., Vučkovič, G., Perš, J., Perš, M., \& Kristan, M. (2008). An analysis of basketball players' movements in the Slovenian basketball league play-offs using the SAGIT tracking system. Facta Universitatis. Series: Physical Education and Sport, 6(1), 75-84.

Girard, O., Mendez-Villanueva, A., \& Bishop, D. (2011). Repeated-sprint ability - part 1, Factors contributing to fatigue. Sports Medicine, 41(8), 673-694.

Gocentas, A., Landõr, A., \& Krisciunas, A. (2011). Heart rate recovery changes during competition period in high-level basketball players. Education and Physical Training in Sport, 80, 11-16.

Green, H., Bishop, P., Houston, M., McKillop, R., Norman, R., \& Stothart, P. (1976). Time, motion and physiological assessments of ice hockey performance. Journal of Applied Physiology, 40(2), 159-163.

Hoffman, J. (2002). Physiological aspects of sport training and performance. Champaign, IL: Human $\mathrm{Ki}-$ netics.

Hůlka, K. (2011). Empirické údaje o výkonu basketbalisty v utkání jako základ plánování tréninkového procesu. Doctoral thesis, Palacký University, Faculty of Physical Culture, Olomouc.

Hůlka, K., \& Stejskal, P. (2005). Diversities in circulation loading of youth basketball players during the match. In The 7th Scientific Conference "Application of Scientific Research on Sport Training". Book of Abstracts (p. 45). Thessaloniki: Aristotle University of Thessaloniki.

Krustrup, P., Mohr, M., \& Ellingsgaard, H. (2005). Physical demands during an elite female soccer 
game: Importance of training status. Medicine and Science in Sports and Exercise, 37(7), 1242-1248.

Krustrup, P., Mohr, M., Nybo, L., Jensen, J. M., Nielsen, J. J., \& Bangsbo, J. (2006). The Yo-Yo IR2 test: Physiological response, reliability and application to elite soccer. Medicine and Science in Sports and Exercise, 38(9), 1666-1673.

Léger, L. A., \& Lambert, J. (1982). A maximal multistage $20 \mathrm{~m}$ shuttle run test to predict $\mathrm{VO}_{2} \max$. European Journal of Applied Physiology and Occupational Physiology, 49(1), 1-12.

Matthew, D., \& Delextrat, A. (2009). Heart rate, blood lactate concentration, and time-motion analysis of female basketball players during competition. Journal of Sports Sciences, 27(8), 813-821.

Matkovič, R. B., Matkovič, B., \& Knajz, D. (2005). Fiziologija košarkaškei gre. Hrvatski Športskomedicinski Vjesnik, 20(2), 113-124.

McInnes, S. E., Carlson, J. S., Jones, C. J., \& McKenna, M. J. (1995). The physiological load imposed on basketball players during competition. Journal of Sports Sciences, 13(5), 387-397.

Montgomery, P. G., Pyne, D. B., \& Minahan, C. L. (2010). The physical and physiological demands of basketball training and competition. International Journal of Sports Physiology and Performance, 5(1), 75-86.

Montgomery, D. L. (1988). Physiology of ice hockey. Sports Medicine, 5(2), 99-126.

Narazaki, K., Berg, K., Stergiou, N., \& Chen, B. (2009). Physiological demands of competitive basketball. Scandinavian Journal of Medicine and Science in Sports, 19(3), 425-432.

Rampinini, E., Bishop, D., Marcora, S. M., Bravo, D. F., Sassi, R., \& Impellizzeri, F. M. (2007). Validity of simple field tests as indicators of match-related physical performance in top-level professional soccer players. International Journal of Sports Medicine, 28(3), 228-235.

Rodriguez-Alonso, M., Fernandez-Garcia, B., PerezLandaluce, J., \& Terrados, N. (2003). Blood lactate and heart rate during national and international women's basketball. Journal of Sports Medicine and Physical Fitness, 43(4), 432-436.

Rudkin, S., \& O’Donoghue, P. G. (2008). Time-motion analysis of first-class cricket fielding. Journal of Science and Medicine in Sport, 11(6), 604-607.

Sallet, P., Perrier, D., Ferret, J. M., Vitelli, V., \& Baverel, G. (2005). Physiological differences in professional basketball players as a function of playing position and level of play. Journal of Sport Medicine and Physical Fitness, 45(3), 291-194.

Sakai, K., Itoh, R., Otaka, T., \& Takamatsu, K. (2006). Effects of physical training based on the individualization principle for ball game athletes. Japan
Journal of Physical Education and Health in Sport Science, 51(1), 21-32.

Sigmon, Ch. (2003). 52 week basketball training. Champaign, IL: Human Kinetics.

Spencer, M., Bishop, D., Dawson, B., \& Goodman, C. (2005). Physiological and metabolic responses of repeated-sprint activities: Specific to field-based team sports. Sports Medicine, 35(12), 1026-1044.

Taylor, J. (2003). Basketball: Applying time motion data to conditioning. Strength and Conditioning Journal, 25(2), 57-64.

Tessitore, A., Tiberi, M., Cortis, C., Rapisarda, E., \& Meeusen, R. (2006). Aerobic-anaerobic profiles, heart rate and match analysis in old basketball players. Gerontology, 52(2), 214-222.

Wadley, G., \& Le Rossignol, P. (1998). The relationship between repeated sprint ability and the aerobic and anaerobic energy system. Journal of Science and Medicine in Sport, 1(2), 100-110.

Wragg, C. B., Maxwell, N. S., \& Doust, J. H. (2000). Evaluation of the reliability and validity of a soccerspecific field test of repeated sprint ability. European Journal of Applied Physiology, 83(1), 77-83.

Ziv, G., \& Lidor, R. (2009). Physical attributes, physiological characteristics, on-court performance and nutritional strategies of female and male basketball players. Sports Medicine, 39(7), 547-568. 


\section{ANALÝZA HERNÍHO VÝKONU HRÁČŮ NEJVYŠŠÍ NÁRODNÍ JUNIORSKÉ SOUTĚŽE BĚHEM UTKÁNÍ V BASKETBALU}

(Souhrn anglického textu)

ÚVOD: Herní výkon hráčů během utkání v basketbalu je intermitentního charakteru díky neustále se proměnuující herním situacím. Pro plánování tréninkového procesu je velmi důležitá znalost herního výkonu hráčů během utkání. Tato znalost tvoří základ pro modelování specifického zatěžování hráčủ během tréninkového procesu.

CíL: Hlavním cílem příspěvku bylo analyzovat indikátory vnějšího a vnitřního zatížení hráčů nejvyšší národní juniorské soutěže během utkání v basketbalu.

METODY: Na výzkumu participovalo 23 hráčů nejvyšší národní juniorské soutěže (věk 16,88 $\pm 0,72$ ). Během šesti přátelských utkání basketbalu byl monitorován průběh srdeční frekvence hráčủ a byla provedena analýza ukazatelů vnějšího zatížení.

VÝSLEDKY: Průměrná srdeční frekvence byla $167,47 \pm 13,01$ tepů za minutu, což odpovídalo $85,06 \pm 6,40 \%$ maximální srdeční frekvence. Průměrná překonaná vzdálenost byla $5880,91 \pm 831,01 \mathrm{~m}$. Interval zatížení a zotavení byl v průměru $1: 7,95 \pm 1,83$ v rozsahu od $1: 4,80$ do $1: 10,92$.

ZÁVĚRY: Výsledky ukazují, že velikost zatižení hráčů během utkání je závislá na hráčské pozici. Pro analýzu herního výkonu je vhodné použivat kombinaci metod pro analýzu vnějšího i vnitřního zatížení.

Klícová slova: intenzita, zatižení, kondiční príprava, maximální srdeční frekvence. 